\begin{tabular}{|c|c|c|}
\hline Mansoura University \\
Faculty of Engineering \\
Mansoura Engineering Journal
\end{tabular}

\title{
Comparative Analyses Based on Simulations to Improve Energy Consumption in Office Buildings in Egypt
}

\begin{tabular}{|l|}
\hline KEYWORDS: \\
Simulation; \\
Comparative Analyses; \\
Building Envelope; \\
Energy Consumption; \\
Finishing Materials
\end{tabular}

LIST OF SYMBOLS

\begin{tabular}{|c|c|}
\hline$F M / s$ & Finishing Material/s \\
\hline$\overline{W W R}$ & Window-to-Wall-Ratio \\
\hline eQuest & The QUick Energy Simulation Tool (a software tool) \\
\hline $\begin{array}{l}\text { Case } \\
\left(\text { Xxi }^{*}\right)\end{array}$ & $\begin{array}{l}\text { In one of the proposed applications, case (Xxi*) denotes } \\
\text { to a studied case with specific dimensions and } \\
\text { orientation, where: (X) is an uppercase/capital letter from } \\
\text { (A) to (E) referring to the length that ranges from } 20 \mathrm{~m} \text { to } \\
100 \mathrm{~m} \text { with } 20 \mathrm{~m} \text { intervals, (x) is a lowercase/small letter } \\
\text { from (a) to (e) denotes the width with the same range and } \\
\text { intervals, (i) represent a number from } 1 \text { to } 3 \text { referring to } \\
\text { the height that ranges from } 20 \mathrm{~m} \text { ( } 5 \text { stories) to } 60 \text { (15 } \\
\text { stories) with } 20 \mathrm{~m} \text { ( } 5 \text { stories) intervals, and }(*) \text { denotes to } \\
\text { the cases oriented } 45 \text { degrees from azimuth, if any. For } \\
\text { example, case (Ce3) refers to the building with } \\
\text { dimensions: 60m (length), 100m (width) and 60m } \\
\text { (height), while case (Ce } 3 * \text { refers to the previous } \\
\text { dimensions with orienting the whole building } 45 \text { degrees } \\
\text { from the azimuth. }\end{array}$ \\
\hline
\end{tabular}

Received: (29 July, 2021) - Revised: (11 August, 2021) - Accepted: (18 August, 2021)

Corresponding Author: Amr Mamdoh Ali Youssef, Assistant Professor in Department of Architectural Engineering, Assiut University, Assiut 71518,Egypt. (email: amr.ma.youssef@aun.edu.eg)

\section{INTRODUCTION}

$\mathrm{B}$ uilding envelope is one of the main domains that can be utilized towards developing net zero energy buildings, especially in hot climate zones. A lot of envelope features can be tracked to reduce energy consumption such as building geometry ratios and others. For instance, changing the geometry ratios of a cubic building (as a feature) from 1:1:1.5 (width: length: height) to 1.75: $1.75: 0.5$ with a same volume (e.g., $96000 \mathrm{~m}^{3}$ ) can reduce the energy consumption from 158.5 to $149.6 \mathrm{kWh} /\left(\mathrm{m}^{2}\right.$.year $)$ in a hot climate zone $(2 \mathrm{~A})^{[1]}$, predicted using eQuest simulation tool [1], and more energy savings per $\mathrm{m}^{2}$ can be reached if the building volume are varied via comparisons. This study aims at determining the sensitivity of envelope

\footnotetext{
${ }^{[1]}$ Based on ASHRAE 90.1 standard, the international climate zones are defined and classified using letters and numbers; letters (A), (B) and (C) denote to moist, dry and marine climate zones, respectively, while numbers (from 1 to 8 ) denote to the temperature (from the hottest to the coldest climate zones), respectively (ASHRAE 2007).
} 
features and their variables along with determining sensitive features and variables that achieves best energy consumption; building geometry ratios, orientations and Finishing materials (FMs) (either covering the roof and/or walls) are the main features to be studied in this paper. However, office buildings have been selected to be studied due to their flexible geometric features, wide façade areas and high energy consumption, and different volumes have been analyzed. Cairo in Egypt, as a hot climate zone, has been used to demonstrate the study outcomes.

Numerous studies conducted analyses on building envelope parameters and design methods towards better energy performance in different climate zones. Ihm and Krarti [2] determined optimal values for the design features of single-family residential buildings in Tunisia to increase their energy efficiency; orientation, window location, Window-to-Wall Ratio (WWR), glazing type, insulation and others systems have been tested. Qian and Lee [3] tested materials and insulations applied on building envelope components (walls, windows, doors and others) in small commercial building using Minitab 17 and TRACETM 700. Ferrara et al [4] developed a framework to find the cost-optimal building configuration for the French single-family building using TRNSYS simulation and GenOpt program. Harmati and Magyar [5] compared glazing influence, preferable WWR and window geometry for better indoor daylight quality and annual energy demand in offices using Radiance simulations. Aksamija [6] discussed design methods for developing sustainable high-performance facades; this include different building treatments, orientations, WWR, shading elements and materials to improve daylighting, energy efficiency and thermal comfort. $\mathrm{Hu}$ and $\mathrm{Wu}$ [7] analyzed the influence of exterior walls, roof, exterior windows and other features for a public building in Beijing to determine sensitive properties.

Moreover, Raji et al [8] studied energy-saving solutions for the envelope design of high-rise office buildings; glazing type, WWR and other strategies through an existing office building in the Netherlands have been studied using DesignBuilder. Barozzi et al [9] reviewed contemporary envelopes via different design approaches for reducing energy consumptions in several examples of spaces, materials and others. Balter et al [10] conducted thermal and energy assessment of different envelope materiality on different residential buildings with massive and light envelopes. Liu et al [11] studied the effect of different orientations, WWR and floor geometric features on artificial lighting in office buildings in Tianjin, China; single and multi-parameter evaluations have been conducted using DesignBuilder. Liu et al [12] conducted energy consumption simulation analyses for a large amount of office buildings; each parameter influence on the energy consumption and optimal combinations have been analyzed. D'Agostino et al [13] demonstrated a decision support framework of building designs that includes different building types, materials and technologies through both environmental and economic criteria. As detailed before, majority of features are relevant to the specific cases or climate zones and should be tested to suit different design cases.

Other studies were focusing on other features such as building geometry (such as shape, ratios and dimensions) reach better energy performance. Tuhus-Dubrow and Krarti [14] developed an approach to minimize energy consumption by optimally selecting shapes, dimensions and other envelope parameters of residential buildings. Zerefos et al [15] examined energy consumption of buildings that have polygonal, orthogonal and prismatic building envelopes located in Mediterranean climates. Finishing and construction materials have been also widely focused for optimization purposes. Al-Nuaimi and Khamis [16] simulated different interior FMs in a single room for reducing its energy consumption in Bahrain; around 7\% energy saving could be achieved. Pukhkal [17] studied protective FMs of exterior walls, structure and others with their effect on heat insulating. Huang et al [18] proposed two most popular retrofitting methods for cooling building wall surfaces in different orientations and climates. Alonso et al [19] studied outer façade FMs' effect on the buildings' energy balance in different thermal conditions; color, solar reflectance and emissivity have been focused on three different construction systems in Madrid, Spain. Echarri-Iribarren et al [20] compared cast recycled aluminium panels with large-format ceramic panels based on their energy savings using EnergyPlus. Khoukhi et al [21] studied retrofitting an office buildings in UAE towards lower energy consumption via building orientation, ventilation, walls and roof construction; wall construction can achieve $4.4 \%$ energy saving in the best case.

In Egypt climate zone in specific, many studies focused on optimizing building envelope features for better energy performance. For example, Albadry [22] proposed a method that combines both retrofitting building envelope with renewable energy strategies that suit the Egyptian context, not new designs. Khalil et al [23] analyzed some design variables and skin configurations of buildings' envelopes in residential buildings' cases in Alexandria, Egypt using Energy Plus simulation, not office buildings, also William et al [24] evaluated the energy efficiency using DesignBuilder simulation in Egyptian existing hospitals. Mahmoud et al [25] conducted a comparative simulation analyses to an administration building in Cairo to assess its performance after applying passive design features such as courtyards, double walled envelope, shading devices and other different features than proposed in this study. Abd ElRahman et al [26] optimized thermal performance of office buildings through building shape, orientation and WWR on a fully glazed office building, not energy consumption. Previous studies did not outline the proposed features on different office buildings in the Egyptian context or highlight relevant guidelines to generic design cases. On the other hand, ASHRAE 90.1 2007 standard is applicable for Cairo climate zone [27], such standards can be utilized to classify features to which can be set to the standards and others to be tested and scoped as detailed in the following section 2. 
Based on the conducted literature, no studies were found providing detailed performance of envelope features and variables in generic cases; some features of building envelope are needed to be studied in their context, such as building geometry that suits different design cases specifically. FMs in different orientations have been also focused to reach better energy performance, while WWR and story height are excluded from the studied variations to be set to the relevant standards as detailed before. To suit different design cases and supports designers' decision, analyses have been conducted via two different applications: application (A) compares energy consumption in cases with a same volume, and application (B) compares energy consumption per $\mathrm{m}^{2}$ in cases with different volumes. The paper has been structured to include details of the proposed features, their variables and relevant classifications in section 2. Section 3 presents two applications ((A) and (B)) to demonstrate the comparison analyses of cases with either the same and different volumes, respectively. Section 4 presents the ranking of best variables' integrations in both applications and most sensitive features/variables. Finally, the discussion and conclusion are detailed in section 5 and 6, respectively, along with the whole simulation results in the appendices.

\section{MAIN FEATURES AND VARIABLES OF BUILDING ENVELOPE AFFECTING ENERGY CONSUMPTION}

Main features of building envelope and their internal variables, that may affect energy consumption, have been selected as shown in Figure 1. Some of these features' variables have been fixed based on ASHRAE 90.1 - 2007 standard; it recommends $10 \%$ to $40 \%$ WWR for office buildings in Cairo climate zone to achieve less energy consumption [27], while high WWR is also recommended from the architectural perspective for providing view visibility and facades attractiveness. Therefore, $40 \%$ WWR has been selected in this study as an medium value that fits ASHREA standards and architectural recommendations. The study focuses on: a) building geometry ratios; b) orientations (every 45 degrees); and c) nine FMs (either covering the roof and/or walls) that have been selected from the common practice and available materials in local markets (detailed in Table 1). All alternatives obtained from different integrations of these features and their variables have been simulated via DOE-2 (eQuest) as detailed below.

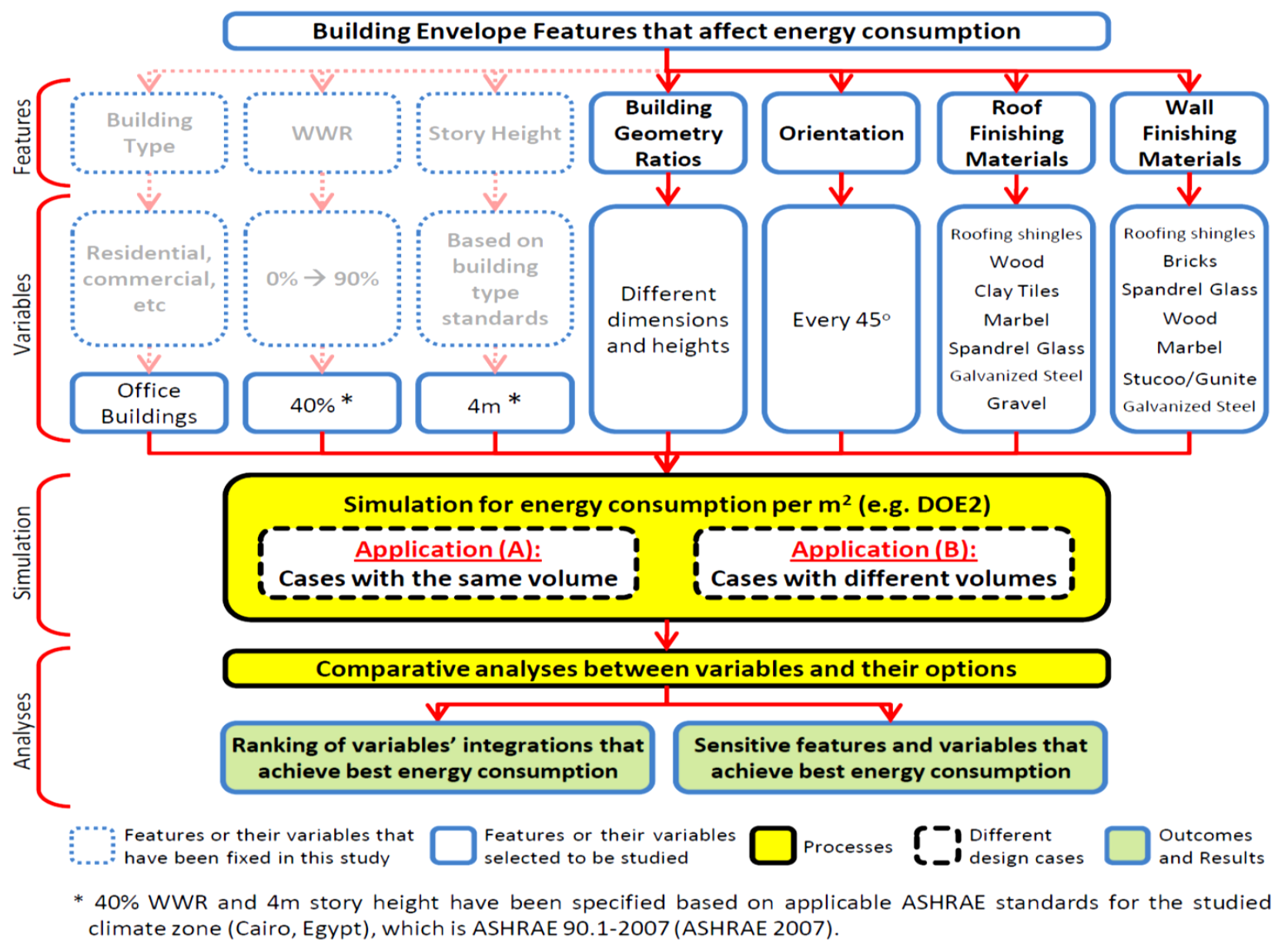

Fig. 1: Main features and variables of building envelope affecting energy consumption 
TABLE 1

FINISHING MATERIALS' SPECIFICATIONS AND CHARACTERISTICS [1]

\begin{tabular}{|c|c|c|c|c|c|c|c|c|}
\hline & $\begin{array}{l}\text { Finishing } \\
\text { Materials }\end{array}$ & Name (Code) In DOE-2 & 总 & 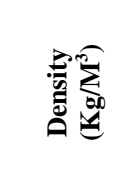 & 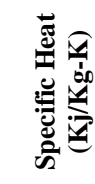 & 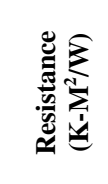 & $\stackrel{n}{\mathscr{0}}$ & 尝 \\
\hline 1 & Gravel & Gravel (RG02) & 2.5 & 881 & 1674 & 0.018 & $\sqrt{ }$ & \\
\hline 2 & Roofing shingles & Wood Shingle (WS01) & 1.7 & 513 & 1255 & 0.153 & $\sqrt{ }$ & $\sqrt{ }$ \\
\hline 3 & Wood & Plywd (PW04) & 1.9 & 545 & 1213 & 0.22 & $\sqrt{ }$ & $\sqrt{ }$ \\
\hline 4 & Galvanized Steel & Steel Siding (ASo1) & 0.15 & 7690 & 480 & $3.3 \times 10^{-5}$ & $\sqrt{ }$ & $\sqrt{ }$ \\
\hline 5 & Stucoo / Gunite & Stucco (SC01) & 2.5 & 2659 & 837 & 0.035 & & $\sqrt{ }$ \\
\hline 6 & Clay Tiles & Clay Tile Paver (CT11) & 1 & 1922 & 837 & 0.005 & $\sqrt{ }$ & \\
\hline 7 & Bricks & Face Brick 4in (BK05) & 10.1 & 2083 & 921 & 0.078 & & $\sqrt{ }$ \\
\hline 8 & Marbel & Terrazzo (TZ01) & 2.5 & 2243 & 837 & 0.014 & $\sqrt{ }$ & $\sqrt{ }$ \\
\hline 9 & Spandrel Glass & 1/4 in Spandrel Glass & 0.625 & 2752 & 840 & - & $\sqrt{ }$ & $\sqrt{ }$ \\
\hline
\end{tabular}

\section{ENERGY CONSUMPTION SIMULATION OF THE ENVELOPE FEATURES IN CUBIC OFFICE BUILDINGS IN EGYPT}

Simulation processes have been conducted on cubic office building in Egypt via two applications as detailed below; the outcome in each application is determining the sensitive features and variables in achieving best energy consumption via a comparative analyses, along with ranking these alternatives.

\subsection{Application (A): Buildings with a same volume}

In this application, previous illustrated features have been simulated using different geometric ratios with the same volume, this is to support designers in comparing different cases that have a fixed architectural program, number of spaces and accordingly a specific context to be formed; a medium volume $\left(96000 \mathrm{~m}^{3}\right)$ have been proposed and outlined in 3 different ratios as shown in Figure 2, and accordingly 8 cases have been conducted after applying possible orientations. The total number of alternatives/simulations conducted using DOE-2 equals 392 alternatives as presented in Figure 3.

By analyzing and ordering the simulation results, it is obvious that cases can be ordered based on energy consumption ascending to case 7 , case 8 , case 3 , case 6 or 4 , case 5 , case 1 and then case 2 . Roof FMs can be also ordered based on energy consumption in the majority of cases ascending to gravel, galvanized steel, glass (spandrel) or marble, clay tiles, wood then roofing shingles, while walls' FMs can be ordered using their energy consumption ascending to galvanized steel, stucoo/gunite, marble, wood, spandrel glass, bricks then roofing shingles. The best alternative through the whole features and variables studied is case 7 with gravel roof and galvanized steel or stucoo walls, while worst alternative is case 2 with roofing shingles in its roof and walls. Appendix (A) shows all the simulation results along with best and worst 10 roof and walls' FMs to be used for each case. As a result, cases 1-2, 3, 4-6 and 7-8 achieve around $3810,3707,3722$ and $3610 \mathrm{MWh} /$ year in average (+/- $0.6 \%)$, respectively.

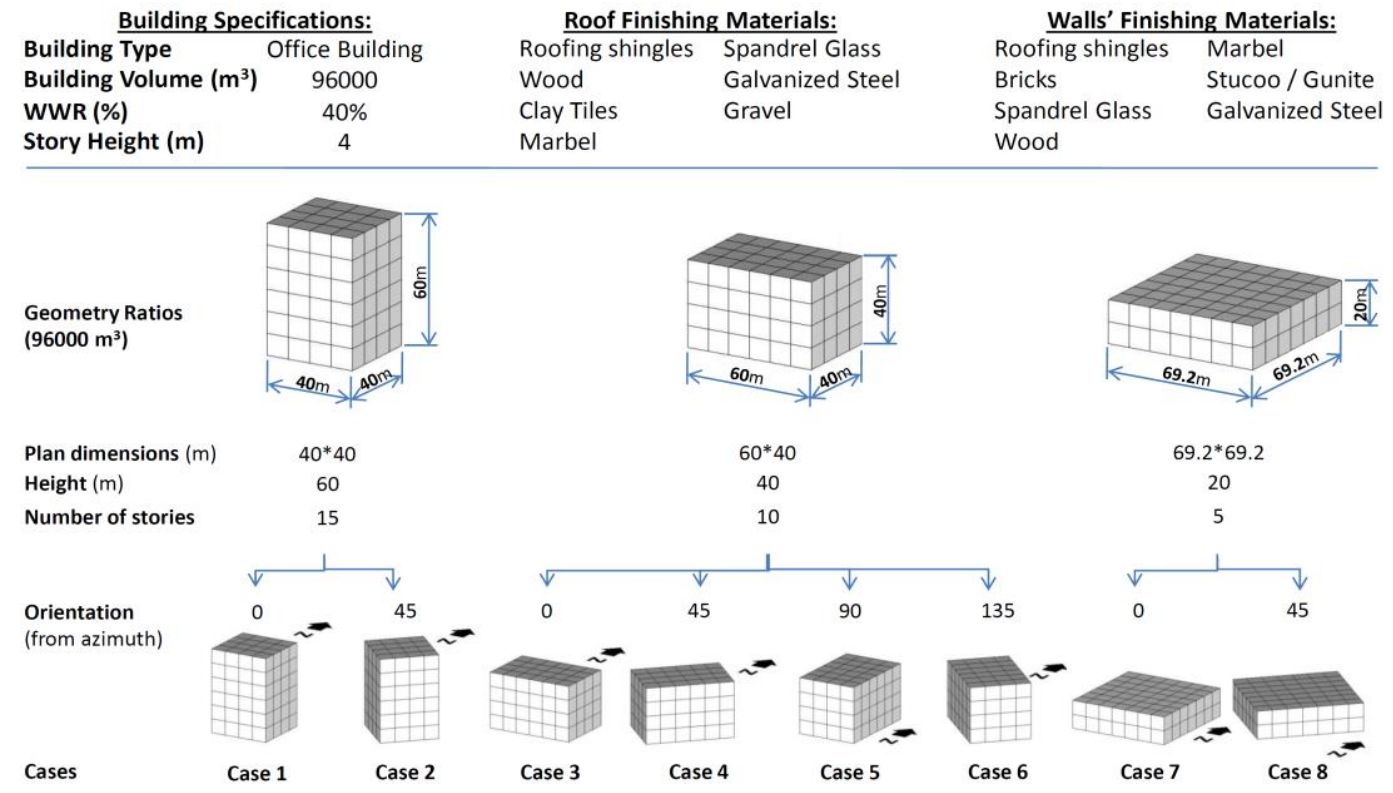

Fig. 2: Cases with a same volume and their specifications to be studied in application (A) 


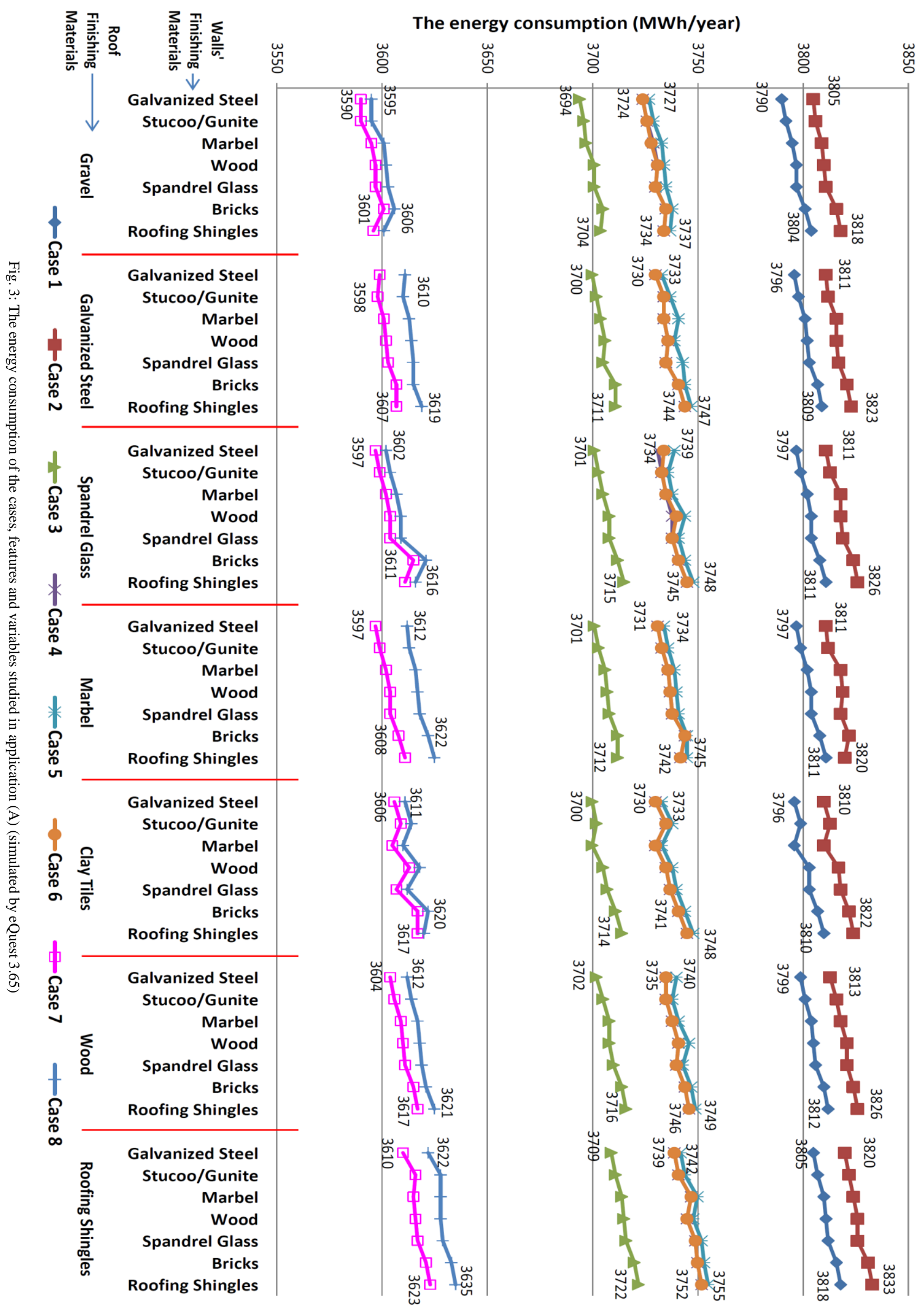




\subsection{Application (B): Buildings with different volumes}

In this application, buildings with different volumes have been tested in different orientations, while FMs' effect on both roof and walls have been ignored due to their weak effect regardless building ratios and orientations as presented in previous application (A). The tested cases in this application are buildings with cubic dimensions starting from $20 \mathrm{~m}$ (length, width or height) with $20 \mathrm{~m}$ intervals in each direction till reaching $100 \mathrm{~m}$ (length or width) and $60 \mathrm{~m}$ (height), also both 0 and 45 orientations from the azimuth have been included (150 total cases). As shown in Figure 4, cases in this application have been denoted to reflect their dimensions and orientation, for example, case (Ce3) refers to the case with dimensions: $60 \mathrm{~m}$ (length $\mathrm{C}$ ), 100m (width e) and $60 \mathrm{~m}$ (height 3 ), while case $\mathrm{Ce} 3 *$ refers to the same previous case with orienting the building 45 degrees from the azimuth. Figure 5 shows the analyses of the energy consumption of cases per $\mathrm{m}^{2}$ in each case, while the simulation results are detailed in Appendix (B).

The results' analyses presented that case (Ee3) achieved the less /energy consumption among all cases and cases (Ee) in different orientations and heights are also the best 6 alternatives, while cases (Aa3) and (Aa3*) have the highest energy consumption. In other words, increasing building length and width causing reducing the energy consumption per $\mathrm{m}^{2}$ in all cases, for example, increasing the width (the side facing east/west direction) from $20 \mathrm{~m}$ (case $\mathrm{Ca} 1$ ) to $100 \mathrm{~m}$ (case $\mathrm{Ce} 1$ ) reduces 27 $\left(\mathrm{kWh} /\left(\mathrm{m}^{2} . \mathrm{yr}\right)\right)$ - around $15.7 \%$, and increasing the length (the side facing north/south direction) from $20 \mathrm{~m}$ (case Ae3) to $100 \mathrm{~m}$ (case Ee3) reduces $20\left(\mathrm{kWh} /\left(\mathrm{m}^{2} . \mathrm{yr}\right)\right)$ around $12.1 \%$. On the other hand, the orientation shows no significant difference in all cases while the majority of cases oriented towards 45 from azimuth have a higher energy consumption per $\mathrm{m}^{2}$ compared to the same cases oriented orthogonally. Figure 6 presents the energy consumption of the three proposed heights (each 5 stories) per $\mathrm{m}^{2}$ in all cases; the height effect can be ignored in the majority of cases since each 5 stories represents around one third of the energy consumption per $\mathrm{m}^{2}$ within a range less than $+/-4 \%$.

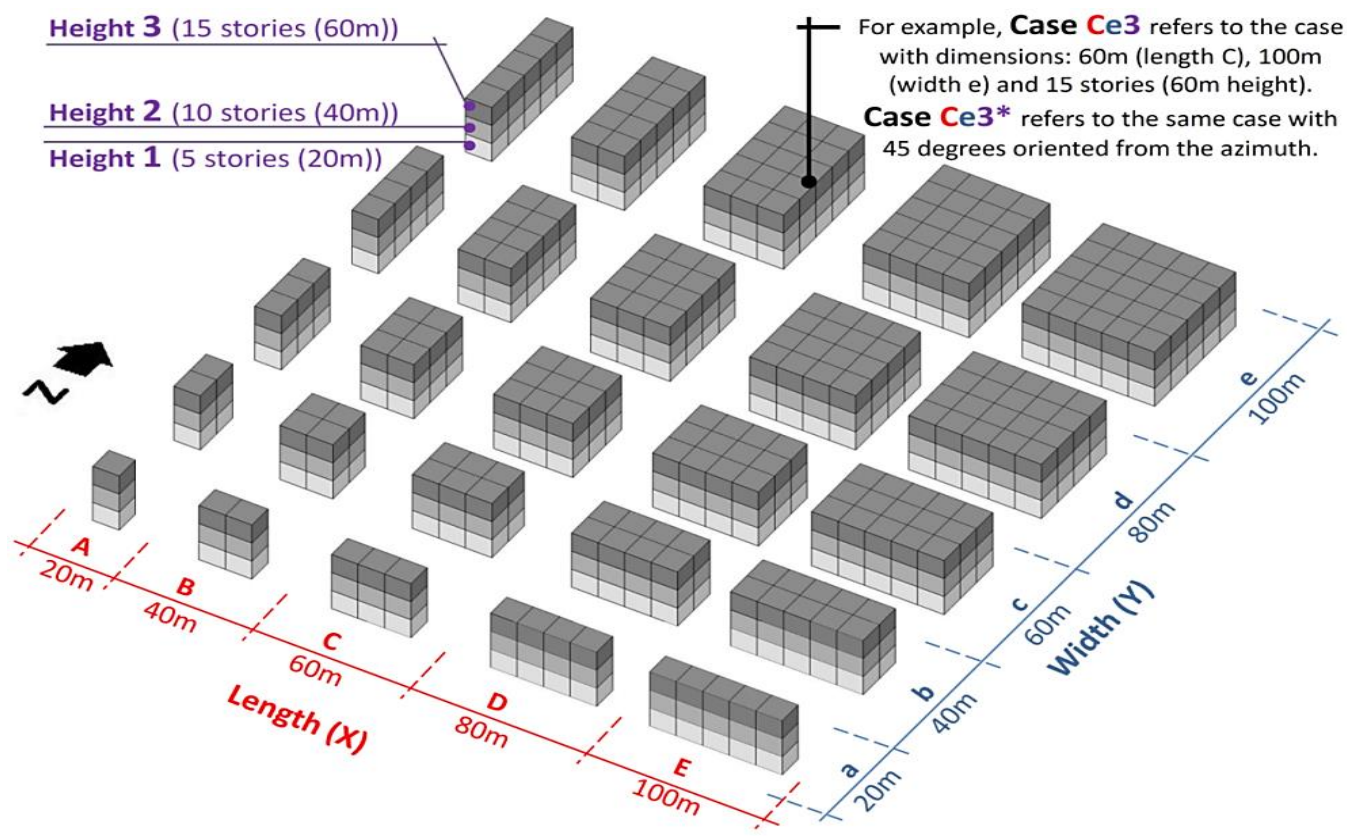

Fig. 4: Cases with different volumes and their specifications to be studied in application (B)

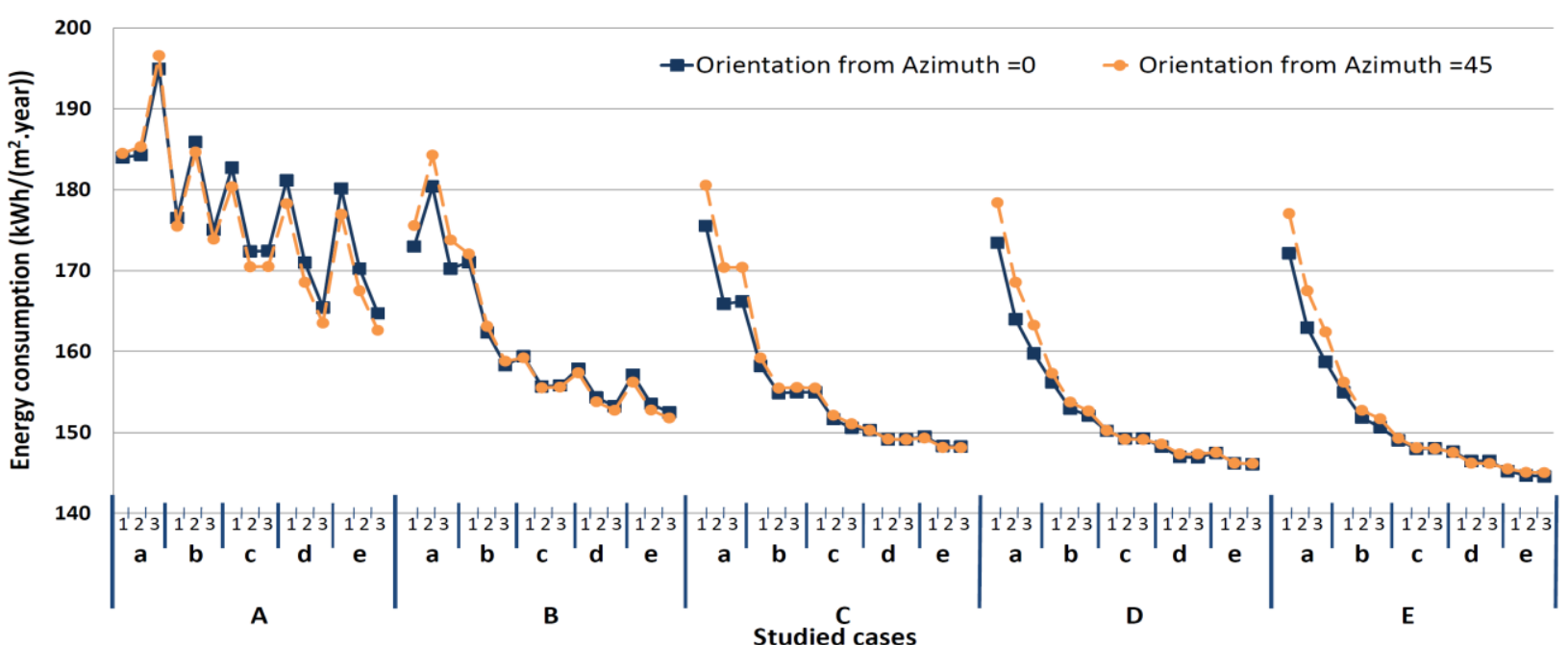

Fig. 5: The energy consumption of cases studied in application (B) 


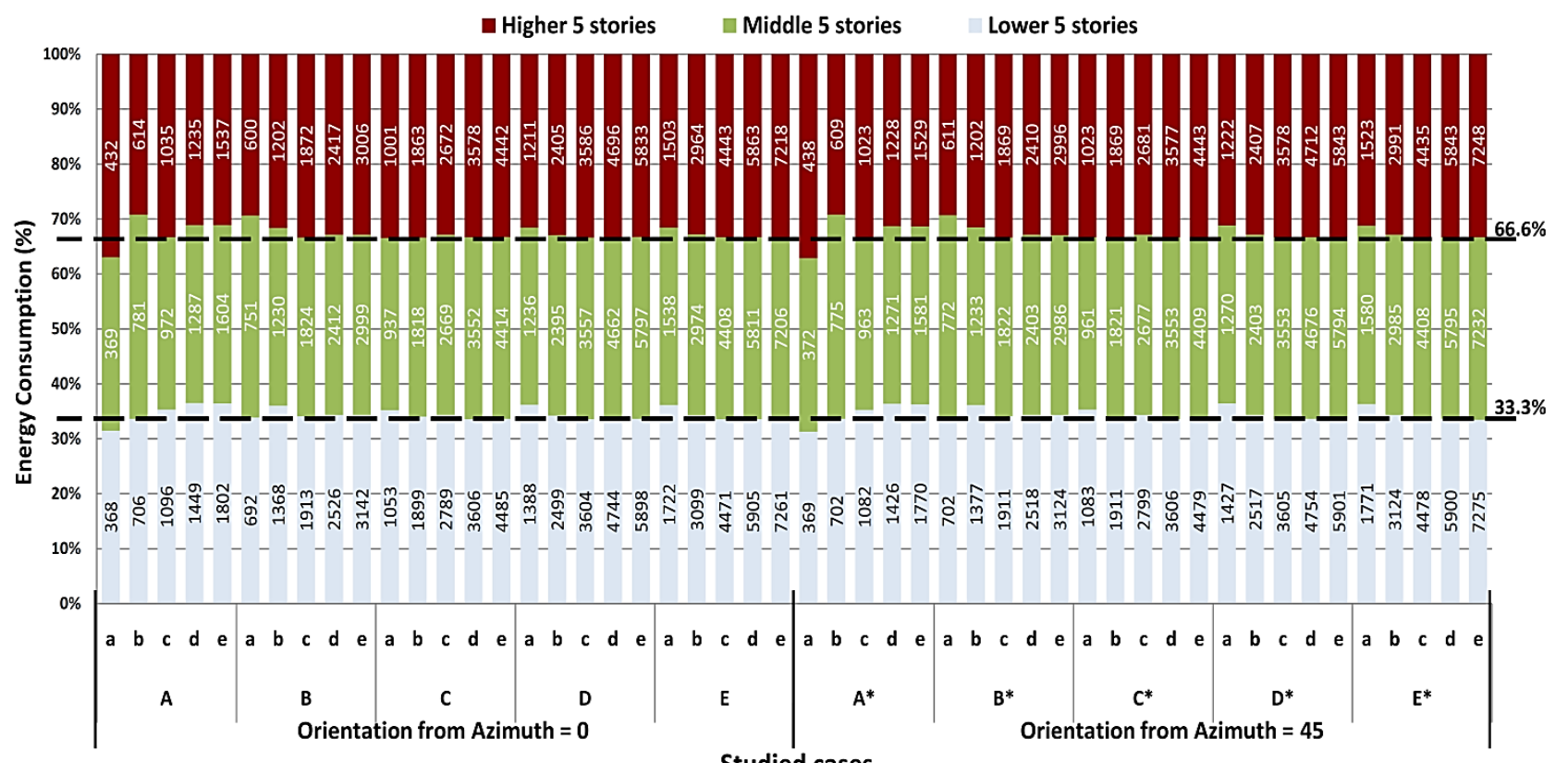

Fig. 6: The effect of building height on the energy consumption of cases studied in application (B)

\section{SENSITIVE FEATURES AND VARIABLES OF BUILDING ENVELOPE AFFECTING ENERGY CONSUMPTION}

It is obvious that the main features and variables studied in both applications have different sensitivity in achieving best energy consumption. As shown in Figure 7 , building ratios are the most sensitive feature among studied ones in both applications (A) and (B) (regardless compared cases have the same or different volumes). In applications (A), $9 \mathrm{kWh} /\left(\mathrm{m}^{2}\right.$.year) energy saving (around
$5.7 \%$ ) can be reached with changing building ratios only in extreme cases, while changing both roof and walls FMs only can reach $1.8 \mathrm{kWh} /\left(\mathrm{m}^{2}\right.$.year) in case 2 (around $1.1 \%$ ). Application (B) presents wider possibility in energy saving due to the flexibility of cases' volume and accordingly ratios; $50 \mathrm{kWh} /\left(\mathrm{m}^{2}\right.$.year) can be reached by changing the building ratios only. Ranking of cases included in applications (A) and (B) are detailed in appendices (A) and (B), respectively.

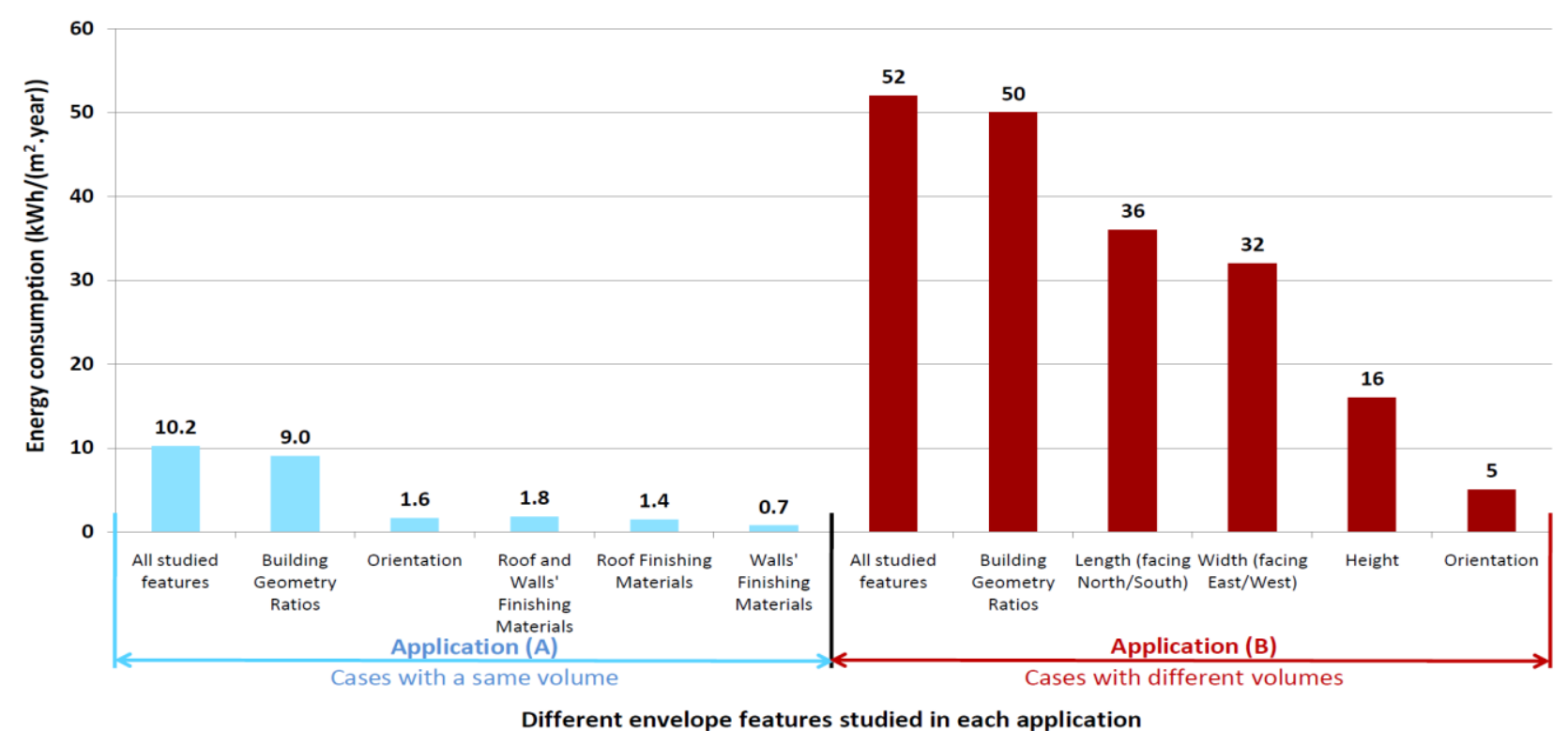

Fig. 7: Maximum energy saving achieved by different building envelope features

\section{DISCUSSION}

The paper illustrated the sensitivity of envelope features for different design cases, and this help designers with a clear suggestions and supportive recommendation while developing their designs. For instance, it can be stated that one complex building with wider dimensions as possible achieves better energy consumption than dividing it to smaller ones; adapting the design in one complex case with $96000 \mathrm{~m}^{3}$ volume (such as cases 1-8, 
case Ad3, case Bc2 separately) achieves within 3600 $3900 \mathrm{MWh} /$ year, while using 5 small cases with the same total volume (such as Aa1-3 together with Ab1-2) achieves more than $4400 \mathrm{MWh} /$ year in total. In flexible design problems such as new buildings in wider layouts, it is recommended to focus building geometry, dimensions and ratios to achieve better energy consumption, while orientation and FMs comes later. More specifically regarding building dimensions, the side that faces north/south direction is more sensitive than the other side, while the height and orientation have very less sensitivity in affecting energy consumption as detailed in application (B). FMs can be used in designs with lower flexibility such as existing buildings, and in such cases, using FMs in roofs have around the double sensitivity compared to FMs in walls especially in cases with wider roofs, for example, altering roof FM in case 7 and 8 in application (A) may reach $29 \mathrm{MWh} /$ year (around 1\%), while altering wall FMs in the same cases can reach only $13 \mathrm{MWh}$ year. However, best FM achieving energy consumption in roofs and walls are gravel and galvanized steel, respectively, while worst one is roofing shingles among both roof and walls' FMs; it is recommended to use other systems besides FMs for more energy savings then. Changing FMs can achieve only $1.1 \%$ energy saving in case 8 due its large volume compared to the envelope area; reducing that ratio increases the probable energy saving since the effect of the envelope features in general and FMs in specific will be increased. In other words, the sensitivity of FMs effect is inversely proportional with the building volume; this is why FMs effect is low although it reaches in a single room (as shown in the literature) to around $4 \%$. Also, the effect of the other features such as building ratios have higher effects in small cases (such as cases $\mathrm{Aa}, \mathrm{Ab}, \mathrm{Ba}$ and others) as shown in previous Figure 5.

However, the study limitations can be outlined in: a) cubic building shapes: sensitive features should be studied within other shapes in future works, such as courtyard dimensions in $U$ shapes, wings length in $\mathrm{L}$ shapes and others, although some features were found in the literature as stated before; b) Hot climate zones: the study can be extended easily towards other climates such as humid and dry zones with less climate temperature; sensitive features and variables may be altered then; c) Applying single FMs in facades: although different integrations of FMs in single facades have not been focused in the study, the performance of applying two or three FMs can be predicted easily from the analyses, since FMs' ranking is clear but not sensitive in the majority of cases, however, aesthetic, thermal and other parameters may be needed then to apply FMs in facades for having better architectural appearance.

\section{CONCLUSION}

This paper presents a simulation-based comparative analyses on building envelope features and their variables from energy consumption perspective. Three main envelope features in cubic office buildings in Egypt have been focused, they are: a) building geometry ratios; b) orientations (every 45 degrees); and c) common envelope finishing materials (FMs): roofing shingles, galvanized steel, wood, marbel and spandrel glass for both roof and walls, also gravel and clay tiles for roofs in addition to stucoo/gunite and bricks for walls. WWR has been set as detailed in ASHRAE 90.1 - 2007 standard for office buildings for Cairo climate zone. However, different cases either with the same or different volumes have been simulated and compared as application (A) and (B), respectively. In application (A), 8 different building cases with the same volume $\left(96000 \mathrm{~m}^{3}\right)$, different ratios and orientations have been prepared along with applying nine FMs on them, hence, 392 simulations have been performed using DOE-2 via eQuest as a simulation tool. In application (B), cubic office buildings have been simulated starting from $20 \mathrm{~m}$ as a unit and repeated intervals. The study outcomes are ranking of features' variables to be used in different cases along with determining sensitive features and best variables; comparative analyses have been conducted accordingly.

By analyzing and ranking the simulation results of cases, best energy consumption can be achieved in application (A) is case 7 (lower height with wider roof oriented by 45 degrees from azimuth), and worst case is case 2 (higher height with narrower roof oriented by 45 degrees from azimuth). Roof FMs can be ordered using their energy consumption ascending to gravel, galvanized steel, spandrel glass or marble, clay tiles, wood then roofing shingles, while walls' FMs can be ordered using their energy consumption ascending to galvanized steel, stucoo/gunite, marble, wood, spandrel glass, bricks, roofing shingles. However, best alternative in application (A) through the whole features studied is case 7 with gravel roof and galvanized steel or stucco walls, while worst alternative is case 2 with roofing shingles in its roof and walls. In application (B), dimensions are also the most sensitive feature as in application (A), while the side that faces north/south direction is more sensitive than the other side. In general, the longer building dimensions the better energy consumption; cases (Ee) in different orientations and heights are the best 6 alternatives, while cases (Aa3) and (Aa3*) have the highest energy consumption. The majority of cases orientated towards 45 from azimuth have a higher energy consumption per $\mathrm{m}^{2}$ compared to the same cases oriented orthogonally, and height effect can be ignored in the majority of cases since each 5 stories represents around approximately one third of the energy consumption per $\mathrm{m}^{2}$.

This comparative and sensitivity analyses are useful in selecting main features to be focused from architects during designing their envelope cases, since not all building envelope features have the same energy effect. More building envelope features and options can be added through to extend the study, beyond what are presented in this paper, such as different building shapes, facade tilting, positions of windows, shades and others. The effect of the economic parameter of such features' integration (e.g. FMs' cost) should be also studied in future works; this parameter may alter the sensitivity and recommendations accordingly. In addition, other evaluation criteria, design preference or priority could extend the study widely, such as cooling, daylighting, energy generation and architectural creativity. A complete computational tool can been developed based on that to 
present best features' variables to fit a set of requirements inserted by an architect to suit a design case with different limitations.

\section{APPENDICES}

APPENDIX (A):

THE SIMULATION RESULTS (ENERGY CONSUMPTION (MWH/YEAR)) OF THE STUDIED CASES IN APPLICATION (A): CASES WITH A SAME VOLUME

\begin{tabular}{|c|c|c|c|c|c|c|c|c|c|c|c|c|}
\hline 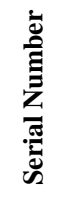 & $\stackrel{\mathscr{a}}{\mathscr{a}}$ & Walls & Case 1 & Case 2 & Case 3 & Case 4 & Case 5 & Case 6 & Case 7 & Case 8 & 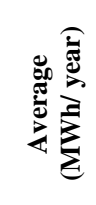 & 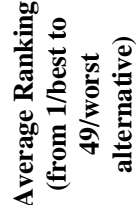 \\
\hline 1 & \multirow{7}{*}{ Uू } & Galvanized Steel & 3790 & 3805 & 3694 & 3724 & 3727 & 3724 & 3590 & 3595 & 3706.1 & 1 \\
\hline 2 & & Stucoo/Gunite & 3792 & 3806 & 3696 & 3726 & 3729 & 3726 & 3590 & 3595 & 3707.5 & 2 \\
\hline 3 & & Marbel & 3795 & 3809 & 3697 & 3729 & 3733 & 3728 & 3595 & 3601 & 3710.9 & 3 \\
\hline 4 & & Wood & 3797 & 3810 & 3701 & 3731 & 3734 & 3731 & 3597 & 3602 & 3712.9 & 4 \\
\hline 5 & & Spandrel Glass & 3797 & 3811 & 3701 & 3730 & 3735 & 3730 & 3597 & 3603 & 3713 & 5 \\
\hline 6 & & Bricks & 3801 & 3816 & 3705 & 3735 & 3738 & 3735 & 3601 & 3606 & 3717.1 & 15 \\
\hline 7 & & Roofing shingles & 3804 & 3818 & 3704 & 3734 & 3737 & 3734 & 3596 & 3601 & 3716 & 13 \\
\hline 8 & \multirow{7}{*}{ 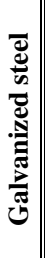 } & Galvanized Steel & 3796 & 3811 & 3700 & 3730 & 3733 & 3730 & 3599 & 3611 & 3713.8 & 6 \\
\hline 9 & & Stucoo/Gunite & 3798 & 3812 & 3702 & 3734 & 3737 & 3734 & 3598 & 3610 & 3715.6 & 12 \\
\hline 10 & & Marbel & 3801 & 3816 & 3704 & 3734 & 3741 & 3734 & 3601 & 3613 & 3718 & 18 \\
\hline 11 & & Wood & 3802 & 3816 & 3706 & 3736 & 3739 & 3736 & 3602 & 3614 & 3718.9 & 21 \\
\hline 12 & & Spandrel Glass & 3803 & 3817 & 3705 & 3735 & 3743 & 3735 & 3603 & 3615 & 3719.5 & 23 \\
\hline 13 & & Bricks & 3807 & 3821 & 3711 & 3741 & 3744 & 3741 & 3607 & 3615 & 3723.4 & 32 \\
\hline 14 & & Roofing shingles & 3809 & 3823 & 3711 & 3744 & 3747 & 3744 & 3607 & 3619 & 3725.5 & 35 \\
\hline 15 & \multirow{7}{*}{ 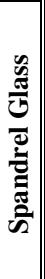 } & Galvanized Steel & 3797 & 3811 & 3701 & 3731 & 3739 & 3734 & 3597 & 3602 & 3714 & 7 \\
\hline 16 & & Stucoo/Gunite & 3799 & 3813 & 3703 & 3733 & 3736 & 3733 & 3599 & 3604 & 3715 & 11 \\
\hline 17 & & Marbel & 3802 & 3818 & 3705 & 3735 & 3738 & 3735 & 3602 & 3607 & 3717.8 & 17 \\
\hline 18 & & Wood & 3804 & 3818 & 3708 & 3738 & 3744 & 3740 & 3604 & 3609 & 3720.6 & 27 \\
\hline 19 & & Spandrel Glass & 3804 & 3819 & 3708 & 3738 & 3741 & 3738 & 3604 & 3609 & 3720.1 & 24 \\
\hline 20 & & Bricks & 3808 & 3824 & 3712 & 3741 & 3744 & 3741 & 3615 & 3621 & 3725.8 & 38 \\
\hline 21 & & Roofing shingles & 3811 & 3826 & 3715 & 3745 & 3748 & 3745 & 3611 & 3616 & 3727.1 & 41 \\
\hline 22 & \multirow{7}{*}{ 岕 } & Galvanized Steel & 3797 & 3811 & 3701 & 3731 & 3734 & 3731 & 3597 & 3612 & 3714.3 & 8 \\
\hline 23 & & Stucoo/Gunite & 3799 & 3812 & 3703 & 3733 & 3736 & 3733 & 3599 & 3613 & 3716 & 14 \\
\hline 24 & & Marbel & 3802 & 3818 & 3706 & 3736 & 3739 & 3736 & 3602 & 3616 & 3719.4 & 22 \\
\hline 25 & & Wood & 3804 & 3819 & 3707 & 3737 & 3740 & 3737 & 3604 & 3617 & 3720.6 & 28 \\
\hline 26 & & Spandrel Glass & 3804 & 3818 & 3708 & 3738 & 3741 & 3738 & 3604 & 3618 & 3721.1 & 29 \\
\hline 27 & & Bricks & 3808 & 3822 & 3712 & 3744 & 3745 & 3744 & 3608 & 3622 & 3725.6 & 36 \\
\hline 28 & & Roofing shingles & 3811 & 3820 & 3712 & 3742 & 3745 & 3742 & 3611 & 3625 & 3726 & 39 \\
\hline 29 & \multirow{7}{*}{ 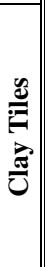 } & Galvanized Steel & 3796 & 3810 & 3700 & 3730 & 3733 & 3730 & 3606 & 3611 & 3714.5 & 10 \\
\hline 30 & & Stucoo/Gunite & 3799 & 3813 & 3702 & 3735 & 3738 & 3735 & 3609 & 3614 & 3718.1 & 19 \\
\hline 31 & & Marbel & 3796 & 3810 & 3700 & 3730 & 3733 & 3730 & 3605 & 3610 & 3714.3 & 9 \\
\hline 32 & & Wood & 3803 & 3817 & 3705 & 3735 & 3738 & 3735 & 3613 & 3618 & 3720.5 & 26 \\
\hline 33 & & Spandrel Glass & 3803 & 3818 & 3707 & 3737 & 3740 & 3737 & 3607 & 3612 & 3720.1 & 25 \\
\hline 34 & & Bricks & 3807 & 3822 & 3711 & 3741 & 3744 & 3741 & 3617 & 3622 & 3725.6 & 37 \\
\hline 35 & & Roofing shingles & 3810 & 3824 & 3714 & 3745 & 3748 & 3745 & 3617 & 3620 & 3727.9 & 43 \\
\hline 36 & \multirow{7}{*}{$\begin{array}{l}\dot{8} \\
\dot{8}\end{array}$} & Galvanized Steel & 3799 & 3813 & 3702 & 3735 & 3740 & 3735 & 3604 & 3612 & 3717.5 & 16 \\
\hline 37 & & Stucoo/Gunite & 3801 & 3816 & 3705 & 3735 & 3738 & 3735 & 3606 & 3614 & 3718.8 & 20 \\
\hline 38 & & Marbel & 3804 & 3818 & 3708 & 3738 & 3741 & 3738 & 3609 & 3617 & 3721.6 & 30 \\
\hline 39 & & Wood & 3805 & 3821 & 3708 & 3741 & 3746 & 3741 & 3610 & 3618 & 3723.8 & 33 \\
\hline 40 & & Spandrel Glass & 3806 & 3821 & 3710 & 3740 & 3743 & 3740 & 3611 & 3619 & 3723.8 & 34 \\
\hline 41 & & Bricks & 3810 & 3824 & 3714 & 3744 & 3747 & 3744 & 3615 & 3621 & 3727.4 & 42 \\
\hline 42 & & Roofing shingles & 3812 & 3826 & 3716 & 3746 & 3749 & 3746 & 3617 & 3625 & 3729.6 & 46 \\
\hline 43 & \multirow{7}{*}{ 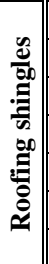 } & Galvanized Steel & 3805 & 3820 & 3709 & 3739 & 3742 & 3739 & 3610 & 3622 & 3723.3 & 31 \\
\hline 44 & & Stucoo/Gunite & 3807 & 3822 & 3711 & 3741 & 3744 & 3741 & 3616 & 3628 & 3726.3 & 40 \\
\hline 45 & & Marbel & 3810 & 3824 & 3714 & 3747 & 3750 & 3747 & 3615 & 3628 & 3729.4 & 45 \\
\hline 46 & & Wood & 3811 & 3826 & 3715 & 3745 & 3748 & 3745 & 3616 & 3628 & 3729.3 & 44 \\
\hline 47 & & Spandrel Glass & 3812 & 3826 & 3716 & 3749 & 3752 & 3749 & 3617 & 3629 & 3731.3 & 47 \\
\hline 48 & & Bricks & 3816 & 3831 & 3720 & 3750 & 3753 & 3750 & 3621 & 3633 & 3734.3 & 48 \\
\hline 49 & & Roofing shingles & 3818 & 3833 & 3722 & 3752 & 3755 & 3752 & 3623 & 3635 & 3736.3 & 49 \\
\hline \multicolumn{3}{|c|}{ Average (MWh/ year) } & 3803 & 3818 & 3707 & 3737 & 3741 & 3737 & 3606 & 3614 & & \\
\hline & \multicolumn{3}{|c|}{$\begin{array}{l}\text { Best } 10 \text { values in each case/ } \\
\text { column (lower energy } \\
\text { consumption) }\end{array}$} & & energ & privin & & & & & $\mathrm{n}$ top and & orst 1 \\
\hline
\end{tabular}


APPENDIX (B)

THE SIMULATION RESULTS (ENERGY CONSUMPTION) OF THE STUDIED CASES IN APPLICATION (B): CASES WITH DIFFERENT VOLUMES

\begin{tabular}{|c|c|c|c|c|c|c|c|c|}
\hline \multicolumn{9}{|c|}{ Orientation from Azimuth $=0$ (Orthogonally) } \\
\hline 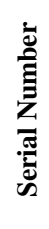 & 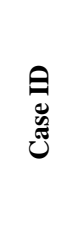 & 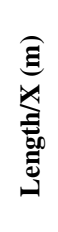 & 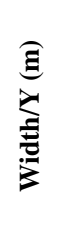 & 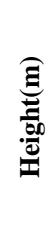 & 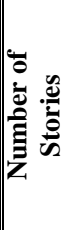 & 矛 & 范 & 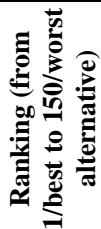 \\
\hline 1 & Aa1 & 20 & 20 & 20 & 5 & 368 & 184 & 142 \\
\hline 2 & Aa2 & 20 & 20 & 40 & 10 & 737 & 184.3 & 144 \\
\hline 3 & $\mathrm{Aa} 3$ & 20 & 20 & 60 & 15 & 1170 & 194.9 & 149 \\
\hline 4 & $\mathrm{Ab} 1$ & 20 & 40 & 20 & 5 & 706 & 176.5 & 131 \\
\hline 5 & $\mathrm{Ab} 2$ & 20 & 40 & 40 & 10 & 1487 & 185.9 & 148 \\
\hline 6 & $\mathrm{Ab3}$ & 20 & 40 & 60 & 15 & 2101 & 175.1 & 127 \\
\hline 7 & Ac1 & 20 & 60 & 20 & 5 & 1096 & 182.7 & 141 \\
\hline 8 & Ac2 & 20 & 60 & 40 & 10 & 2069 & 172.4 & 121 \\
\hline 9 & Ac3 & 20 & 60 & 60 & 15 & 3104 & 172.4 & 122 \\
\hline 10 & Ad1 & 20 & 80 & 20 & 5 & 1449 & 181.2 & 140 \\
\hline 11 & $\mathrm{Ad} 2$ & 20 & 80 & 40 & 10 & 2736 & 171 & 117 \\
\hline 12 & $\mathrm{Ad} 3$ & 20 & 80 & 60 & 15 & 3970 & 165.4 & 104 \\
\hline 13 & Ae1 & 20 & 100 & 20 & 5 & 1802 & 180.2 & 136 \\
\hline 14 & $\mathrm{Ae} 2$ & 20 & 100 & 40 & 10 & 3405 & 170.3 & 112 \\
\hline 15 & Ae3 & 20 & 100 & 60 & 15 & 4942 & 164.7 & 103 \\
\hline 16 & Ba1 & 40 & 20 & 20 & 5 & 692 & 173 & 123 \\
\hline 17 & $\mathrm{Ba} 2$ & 40 & 20 & 40 & 10 & 1443 & 180.4 & 138 \\
\hline 18 & $\mathrm{Ba} 3$ & 40 & 20 & 60 & 15 & 2043 & 170.2 & 111 \\
\hline 19 & Bb1 & 40 & 40 & 20 & 5 & 1368 & 171 & 118 \\
\hline 20 & $\mathrm{Bb} 2$ & 40 & 40 & 40 & 10 & 2598 & 162.4 & 95 \\
\hline 21 & $\mathrm{Bb3}$ & 40 & 40 & 60 & 15 & 3799 & 158.3 & 88 \\
\hline 22 & $\mathrm{Bc} 1$ & 40 & 60 & 20 & 5 & 1913 & 159.4 & 93 \\
\hline 23 & $\mathrm{Bc} 2$ & 40 & 60 & 40 & 10 & 3736 & 155.7 & 78 \\
\hline 24 & $\mathrm{Bc} 3$ & 40 & 60 & 60 & 15 & 5608 & 155.8 & 79 \\
\hline 25 & Bd1 & 40 & 80 & 20 & 5 & 2526 & 157.9 & 86 \\
\hline 26 & $\mathrm{Bd} 2$ & 40 & 80 & 40 & 10 & 4938 & 154.3 & 68 \\
\hline 27 & $\mathrm{Bd} 3$ & 40 & 80 & 60 & 15 & 7355 & 153.2 & 64 \\
\hline 28 & $\mathrm{Be} 1$ & 40 & 100 & 20 & 5 & 3142 & 157.1 & 83 \\
\hline 29 & $\mathrm{Be} 2$ & 40 & 100 & 40 & 10 & 6141 & 153.5 & 65 \\
\hline 30 & $\mathrm{Be} 3$ & 40 & 100 & 60 & 15 & 9148 & 152.5 & 58 \\
\hline 31 & $\mathrm{Ca} 1$ & 60 & 20 & 20 & 5 & 1053 & 175.5 & 129 \\
\hline 32 & $\mathrm{Ca} 2$ & 60 & 20 & 40 & 10 & 1991 & 165.9 & 105 \\
\hline 33 & $\mathrm{Ca} 3$ & 60 & 20 & 60 & 15 & 2991 & 166.2 & 106 \\
\hline 34 & Cb1 & 60 & 40 & 20 & 5 & 1899 & 158.2 & 87 \\
\hline 35 & $\mathrm{Cb} 2$ & 60 & 40 & 40 & 10 & 3716 & 154.9 & 69 \\
\hline 36 & Cb3 & 60 & 40 & 60 & 15 & 5579 & 155 & 72 \\
\hline 37 & $\mathrm{Cc} 1$ & 60 & 60 & 20 & 5 & 2789 & 154.9 & 70 \\
\hline 38 & $\mathrm{Cc} 2$ & 60 & 60 & 40 & 10 & 5458 & 151.6 & 52 \\
\hline 39 & $\mathrm{Cc} 3$ & 60 & 60 & 60 & 15 & 8130 & 150.6 & 49 \\
\hline 40 & $\mathrm{Cd} 1$ & 60 & 80 & 20 & 5 & 3606 & 150.3 & 47 \\
\hline 41 & $\mathrm{Cd} 2$ & 60 & 80 & 40 & 10 & 7158 & 149.1 & 37 \\
\hline 42 & $\mathrm{Cd} 3$ & 60 & 80 & 60 & 15 & 10737 & 149.1 & 34 \\
\hline 43 & $\mathrm{Ce} 1$ & 60 & 100 & 20 & 5 & 4485 & 149.5 & 44 \\
\hline 44 & $\mathrm{Ce} 2$ & 60 & 100 & 40 & 10 & 8899 & 148.3 & 31 \\
\hline 45 & $\mathrm{Ce} 3$ & 60 & 100 & 60 & 15 & 13341 & 148.2 & 29 \\
\hline 46 & Da1 & 80 & 20 & 20 & 5 & 1388 & 173.4 & 124 \\
\hline 47 & $\mathrm{Da} 2$ & 80 & 20 & 40 & 10 & 2624 & 164 & 102 \\
\hline 48 & Da3 & 80 & 20 & 60 & 15 & 3834 & 159.8 & 94 \\
\hline 49 & Db1 & 80 & 40 & 20 & 5 & 2499 & 156.2 & 80 \\
\hline 50 & $\mathrm{Db} 2$ & 80 & 40 & 40 & 10 & 4894 & 152.9 & 63 \\
\hline 51 & $\mathrm{Db3}$ & 80 & 40 & 60 & 15 & 7299 & 152.1 & 56 \\
\hline 52 & Dc1 & 80 & 60 & 20 & 5 & 3604 & 150.2 & 45 \\
\hline 53 & Dc2 & 80 & 60 & 40 & 10 & 7161 & 149.2 & 40 \\
\hline 54 & Dc3 & 80 & 60 & 60 & 15 & 10747 & 149.3 & 42 \\
\hline 55 & Dd1 & 80 & 80 & 20 & 5 & 4744 & 148.2 & 30 \\
\hline 56 & Dd2 & 80 & 80 & 40 & 10 & 9406 & 147 & 16 \\
\hline 57 & $\mathrm{Dd} 3$ & 80 & 80 & 60 & 15 & 14102 & 146.9 & 15 \\
\hline 58 & De1 & 80 & 100 & 20 & 5 & 5898 & 147.5 & 19 \\
\hline 59 & $\overline{\mathrm{De} 2}$ & 80 & 100 & 40 & 10 & 11695 & 146.2 & 12 \\
\hline 60 & De3 & 80 & 100 & 60 & 15 & 17528 & 146.1 & 7 \\
\hline 61 & Ea1 & 100 & 20 & 20 & 5 & 1722 & 172.2 & 120 \\
\hline 62 & $\mathrm{Ea} 2$ & 100 & 20 & 40 & 10 & 3259 & 163 & 98 \\
\hline
\end{tabular}

\begin{tabular}{l||l||l||l||l||l||l||l||l}
\hline 63 & Ea3 & 100 & 20 & 60 & 15 & 4762 & 158.7 & 89 \\
\hline 64 & Eb1 & 100 & 40 & 20 & 5 & 3099 & 155 & 71 \\
\hline 65 & Eb2 & 100 & 40 & 40 & 10 & 6074 & 151.8 & 55 \\
\hline 66 & Eb3 & 100 & 40 & 60 & 15 & 9038 & 150.6 & 50 \\
\hline 67 & Ec1 & 100 & 60 & 20 & 5 & 4471 & 149 & 33 \\
\hline 68 & Ec2 & 100 & 60 & 40 & 10 & 8878 & 148 & 23 \\
\hline 69 & Ec3 & 100 & 60 & 60 & 15 & 13321 & 148 & 25 \\
\hline 70 & Ed1 & 100 & 80 & 20 & 5 & 5905 & 147.6 & 22 \\
\hline 71 & Ed2 & 100 & 80 & 40 & 10 & 11716 & 146.4 & 13 \\
\hline 72 & Ed3 & 100 & 80 & 60 & 15 & 17579 & 146.5 & 14 \\
\hline 73 & Ee1 & 100 & 100 & 20 & 5 & 7261 & 145.2 & 5 \\
\hline 74 & Ee2 & 100 & 100 & 40 & 10 & 14467 & 144.7 & 2 \\
\hline 75 & Ee3 & 100 & 100 & 60 & 15 & 21685 & 144.6 & 1
\end{tabular}

\begin{tabular}{|c|c|c|c|c|c|c|c|c|}
\hline \multicolumn{9}{|c|}{ Orientation from Azimuth $=\mathbf{4 5}$} \\
\hline 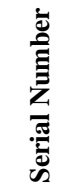 & 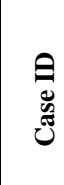 & 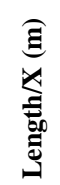 & 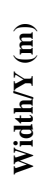 & 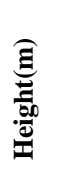 & 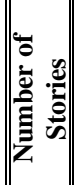 & 㐏 & 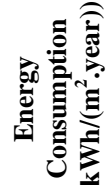 & \\
\hline
\end{tabular}

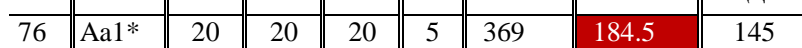

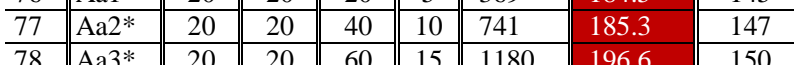
\begin{tabular}{c|l||c||c||c||c||c|c|c|}
\hline 78 & $\mathrm{Ab} 1 *$ & 20 & 40 & 20 & 5 & 702 & 175.5 & 128 \\
\hline 79 & $\mathrm{Ab} *$ & 20 & 40 & 40 & 10 & 1477 & 184.7 & 146 \\
\hline
\end{tabular}

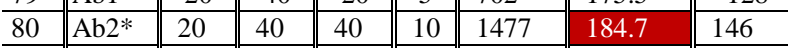
\begin{tabular}{|l||l||l||l||l||l||l||l||l|}
\hline 81 & Ab3* $^{*}$ & 20 & 40 & 60 & 15 & 2087 & 173.9 & 126 \\
\hline
\end{tabular}

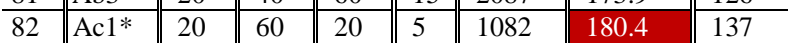

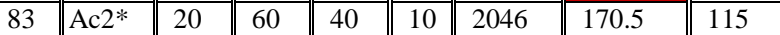

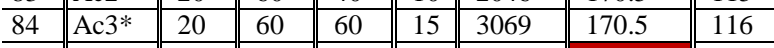

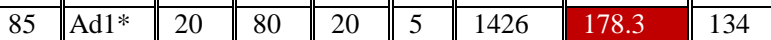

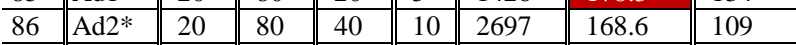
\begin{tabular}{|l|l||l||l||l||l||l|l||l|}
\hline 87 & Ad3* & 20 & 80 & 60 & 15 & 3924 & 163.5 & 101 \\
\hline
\end{tabular}

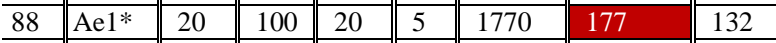

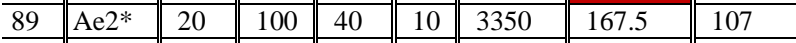

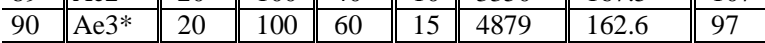

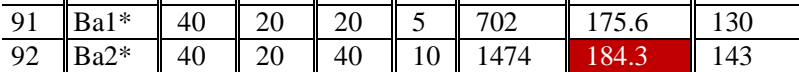

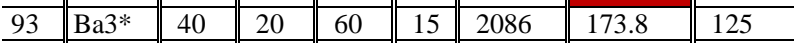
\begin{tabular}{l||l||l||l||l||l||l||l||l}
\hline 94 & Bb1* & 40 & 40 & 20 & 5 & 1377 & 172.1 & 119 \\
\hline 95 & Bb2* & 40 & 40 & 40 & 10 & 2610 & 163.1 & 99
\end{tabular}

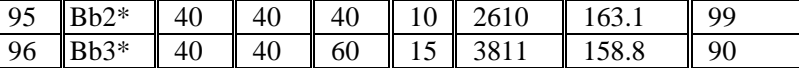

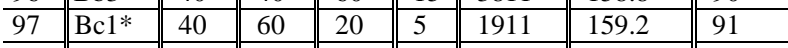

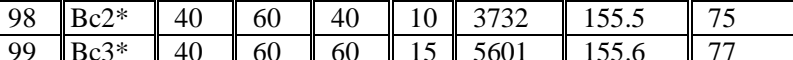

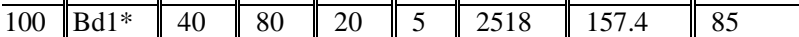

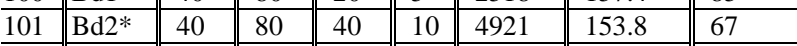

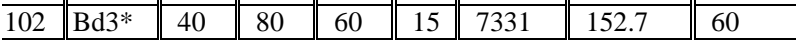
\begin{tabular}{l||l||l||l||l||l||l||l||l|}
\hline 103 & Be1* $^{*}$ & 40 & 100 & 20 & 5 & 3124 & 156.2 & 82 \\
\hline
\end{tabular} \begin{tabular}{|l||l||l||l|l||l||l||l||l|}
\hline 104 & Be2* & 40 & 100 & 40 & 10 & 6110 & 152.8 & 62 \\
\hline
\end{tabular}

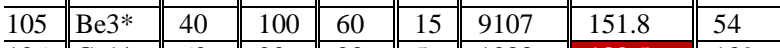

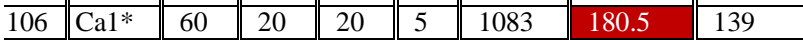

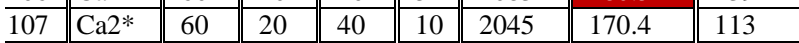
\begin{tabular}{|l||l||l||l|l|l||l||l||l|}
\hline 108 & Ca3* $^{*}$ & 60 & 20 & 60 & 15 & 3067 & 170.4 & 114 \\
\hline
\end{tabular}

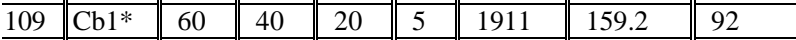
\begin{tabular}{l|l||l||l|l||l||l||l|l|}
\hline 110 & $\mathrm{Cb}^{*}$ & 60 & 40 & 40 & 10 & 3731 & 155.5 & 73 \\
\hline
\end{tabular} \begin{tabular}{l||l||l||l||l|l||l||l||l|}
\hline 111 & $\mathrm{Cb} 3 *$ & 60 & 40 & 60 & 15 & 5600 & 155.6 & 76 \\
\hline 112 & $\mathrm{Cc} 1 *$ & 60 & 60 & 20 & 5 & 2799 & 155.5 & 74 \\
\hline
\end{tabular}

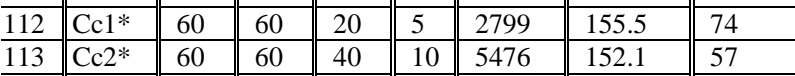
\begin{tabular}{l|l||l||l||l|l||l|l|l|l|}
\hline 113 & Cc2* & 60 & 60 & 40 & 10 & 5476 & 152.1 & 57 \\
\hline 114 & Cc3* & 60 & 60 & 60 & 15 & 8157 & 151.1 & 51 \\
\hline
\end{tabular} \begin{tabular}{l|l||l||l|l|l||l||l||l|}
\hline 115 & $\mathrm{Cd}^{*} *$ & 60 & 80 & 20 & 5 & 3606 & 150.3 & 48 \\
\hline
\end{tabular}

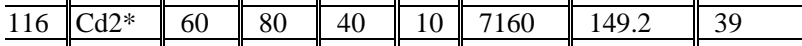
\begin{tabular}{|l||l||l||l||l||l||l||l||l|}
\hline 117 & Cd3* & 60 & 80 & 60 & 15 & 10737 & 149.1 & 35 \\
\hline
\end{tabular}

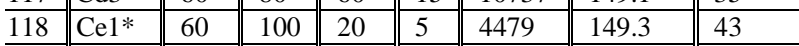
\begin{tabular}{l|l||l||l|l|l||l||l||l|l|}
\hline 119 & $\mathrm{Ce}^{*} *$ & 60 & 100 & 40 & 10 & 8888 & 148.1 & 28 \\
\hline
\end{tabular}

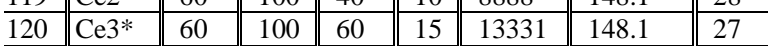

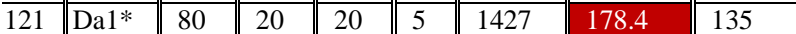
\begin{tabular}{l||l||l||l|l||l||l||l|l|}
\hline 122 & $\mathrm{Da}^{*}$ & 80 & 20 & 40 & 10 & 2697 & 168.6 & 110 \\
\hline 123 & $\mathrm{Da3}$ & 80 & 20 & 60 & 15 & 3918 & 163.3 & 100 \\
\hline
\end{tabular} \begin{tabular}{l||l||l||l|l||l||l||l||l|}
\hline 123 & Da3* & 80 & 20 & 60 & 15 & 3918 & 163.3 & 100 \\
\hline
\end{tabular}

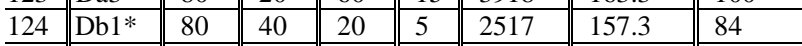

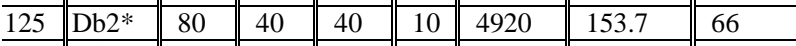
\begin{tabular}{l||l||l||l||l|l||l||l|l|}
\hline 126 & Db3* $^{*}$ & 80 & 40 & 60 & 15 & 7327 & 152.6 & 59 \\
\hline 127 & $\mathrm{Dc}^{*}$ & 80 & 60 & 20 & 5 & 3605 & 150.2 & 46 \\
\hline
\end{tabular}

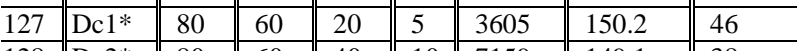

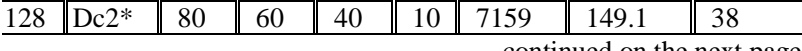


APPENDIX (B):: continued

\begin{tabular}{|c|c|c|c|c|c|c|c|c|}
\hline \multicolumn{9}{|c|}{ Orientation from Azimuth $=45$} \\
\hline 离 & 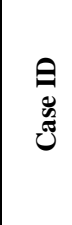 & 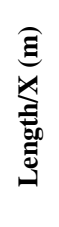 & 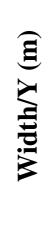 & 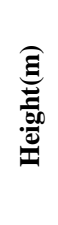 & 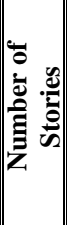 & 㞼 & 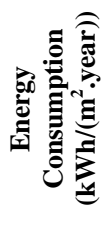 & 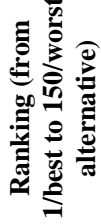 \\
\hline 129 & Dc3* & 80 & 60 & 60 & 15 & 10737 & 149.1 & 36 \\
\hline 130 & Dd1* & 80 & 80 & 20 & 5 & 4754 & 148.6 & 32 \\
\hline 131 & $\mathrm{Dd} 2 *$ & 80 & 80 & 40 & 10 & 9430 & 147.3 & 18 \\
\hline 132 & Dd3* & 80 & 80 & 60 & 15 & 14142 & 147.3 & 17 \\
\hline 133 & De1* & 80 & 100 & 20 & 5 & 5901 & 147.5 & 21 \\
\hline 134 & De2* & 80 & 100 & 40 & 10 & 11695 & 146.2 & 10 \\
\hline 135 & De3* & 80 & 100 & 60 & 15 & 17538 & 146.1 & 8 \\
\hline 136 & Ea1* & 100 & 20 & 20 & 5 & 1771 & 177.1 & 133 \\
\hline 137 & $\mathrm{Ea} 2 *$ & 100 & 20 & 40 & 10 & 3350 & 167.5 & 108 \\
\hline 138 & Ea3* & 100 & 20 & 60 & 15 & 4873 & 162.4 & 96 \\
\hline 139 & Eb1* & 100 & 40 & 20 & 5 & 3124 & 156.2 & 81 \\
\hline 140 & $\mathrm{~Eb} 2 *$ & 100 & 40 & 40 & 10 & 6109 & 152.7 & 61 \\
\hline 141 & Eb3* & 100 & 40 & 60 & 15 & 9101 & 151.7 & 53 \\
\hline 142 & Ec1* & 100 & 60 & 20 & 5 & 4478 & 149.3 & 41 \\
\hline 143 & Ec2* & 100 & 60 & 40 & 10 & 8886 & 148.1 & 26 \\
\hline 144 & Ec3* & 100 & 60 & 60 & 15 & 13321 & 148 & 24 \\
\hline 145 & Ed1* & 100 & 80 & 20 & 5 & 5900 & 147.5 & 20 \\
\hline 146 & $\mathrm{Ed} 2 *$ & 100 & 80 & 40 & 10 & 11695 & 146.2 & 11 \\
\hline 147 & Ed3* & 100 & 80 & 60 & 15 & 17538 & 146.1 & 9 \\
\hline 148 & Ee1* & 100 & 100 & 20 & 5 & 7275 & 145.5 & 6 \\
\hline 149 & Ee2* & 100 & 100 & 40 & 10 & 14507 & 145.1 & 4 \\
\hline 150 & Ee3* & 100 & 100 & 60 & 15 & 21755 & 145 & 3 \\
\hline
\end{tabular}

Best 20 values (lower energy consumption)

Worst 20 values (higher energy consumption)
Different Envelope Materiality Above and Below Tree Canopy. $\begin{array}{llll}\text { Energy } & \text { and } & \text { Buildings }\end{array}$ https://doi.org/10.1016/j.enbuild.2015.11.011.

[11] L. Liu, D. Wu1, X. Li, Sh. Hou, C. Liu, Ph. Jones (2017). Effect of Geometric Factors on The Energy Performance of High-rise Office Towers in Tianjin, China. Building Simulation, 10: 625-641. https://doi.org/10.1007/s12273-017-0359-y

[12] Y. Liu, S. Zou, H. Chen, X. Wu, W. Chen (2019) Simulation Analysis and Scheme Optimization of Energy Consumption in Public Buildings. Advances in Civil Engineering 2019: 6326138. https://doi.org/10.1155/2019/6326138.

[13] D. D'Agostino, D. Parker, P. Melià (2019) Environmental and Economic Implications of Energy Efficiency in New Residential Buildings: A Multi-Criteria Selection Approach. Energy Strategy Reviews26: 100412 https://doi.org/10.1016/j.esr.2019.100412.

[14] D. Tuhus-Dubrow, M. Krarti (2010). Genetic-Algorithm Based Approach to Optimize Building Envelope Design for Residential Buildings. Energy and Buildings 45: 1574-1581. https://doi.org/10.1016/j.buildenv.2010.01.005.

[15] S.C. Zerefos, C.A. Tessas, A.M. Kotsiopoulos, D. Founda, A Kokkini (2012) The Role of Building Form in Energy Consumption: The Case of A Prismatic Building in Athens. Energy and Buildings 48: 97-102. https://doi.org/10.1016/j.enbuild.2012.01.014.

[16] S.F. Al-Nuaimi, Kh.A. Khamis (2014) Thermal Impact Of Different Interior Finishing Materials On Energy Consumption in Bahrain. Journal of Energy Technologies and Policy 4:3: 30-49. Available via:

https://www.iiste.org/Journals/index.php/JETP/article/view/1166 3. Accessed at July 2021.

[17] V. Pukhkal (2015) Humidity Conditions for Exterior Walls Insulation (Case Study of Residential Housing Development in Saint-Petersburg). Procedia Engineering 117: 616-623. https://doi.org/10.1016/j.proeng.2015.08.222.

[18] Y. Huang, R. Qi, L. Mi (2017) Investigation on Energy-Efficient Retrofitting Measures on Commercial Building External Walls in Cooling-Dominate Cities. Energy and Buildings 205: 2973-2979. https://doi.org/10.1016/j.proeng.2017.10.115.

[19] C. Alonso, F. Martín-Consuegra , I. Oteiza, E. Asensio, G. Pérez, I. Martínez, B. Frutos (2017) Effect of Façade Surface Finish on Building Energy Rehabilitation. Solar Energy 146: 470-483. https://doi.org/10.1016/j.solener.2017.03.009.

\section{REFERENCES}

[1] DOE-2 (2020) DOE-2 based software homepage, eQuest. Available via http://www.doe2.com/equest.Accessed at 20 June 2020.

[2] P. Ihm, M. Krarti (2013) Design Optimization of Energy Efficient Office Buildings in Tunisia. Building and Environment 58(4):8190. https://doi.org/10.1016/j.buildenv.2012.06.012.

[3] X. Qian, S.W. Lee (2014) The Design and Analysis of Energy Efficient Building Envelopes for the Commercial Buildings by Mixed-Level Factorial Design and Statistical Methods. Proceeding of Fall 2014 Middle Atlantic American Society of Engineering, Swarthmsore College in Swartz Creek, US. Available via: https://www.semanticscholar.org/paper/. Accessed at 1 Apr 2021.

[4] M. Ferrara, E. Fabrizio, J. Virgone, M. Filippi (2014) A Simulation-Based Optimization Method for Cost-Optimal Analysis of Nearly Zero Energy Buildings. Energy and Buildings 84:442457. https://doi.org/10.1016/j.enbuild.2014.08.031.

[5] N. Harmati, Z. Magyar (2015) Influence of WWR, WG and Glazing Properties on The Annual Heating and Cooling Energy Demand in Buildings. Energy Procedia78: 2458-2463. https://doi.org/10.1016/j.egypro.2015.11.229.

[6] A. Aksamija (2015) High-performance building envelopes: design methods for energy efficient facades. Proceedings of: BEST4 Conference, USA

[7] J. Hu, J. Wu (2015) Analysis on the Influence of Building Envelope to public buildings energy consumption based on DeST simulation. Procedia Engineering 121: 1620-1627 https://doi.org/10.1016/j.proeng.2015.09.192.

[8] B. Raji, M.J. Tenpierik, A. Van den Dobbelsteen (2016) An assessment of energy-saving solutions for the envelope design of high-rise buildings in temperate climates: A case study in the Netherlands. Energy and Buildings124: 210-221. https://doi.org/10.1016/j.enbuild.2015.10.049.

[20] V. Echarri-Iribarren, F. Echarri-Iribarren, C. Rizo-Maestre (2019) Ceramic Panels Versus Aluminium in Buildings: Energy Consumption and Environmental Impact Assessment with a New Methodology. Applied Energy233-234: 959-974. https://doi.org/10.1016/j.apenergy.2018.08.091.

[21] M. Khoukhi, A.F.Darsaleh, S. Ali (2020) Retrofitting an Existing Office Building in the UAE Towards Achieving Low-Energy Building. $\quad$ Sustainability 2573. https://doi.org/10.3390/su12062573.

[22] S. Albadry (2016) Feasibility of Converting Existing Residential Buildings to Net Zero-Energy Buildings in Egypt. M.Sc, Center for Sustainable Development, The American University of Cairo, Egypt. Available via: http://dar.aucegypt.edu/handle/10526/4771. Accessed at: 1 Jan 2021.

[23] A. Khalil, M. Fikry, W. Abdeaal (2018) High Technology or Low Technology for Buildings Envelopes in Residential Buildings in Egypt. Alexandria Engineering Journal57(4): 3779-3792. https://doi.org/10.1016/j.aej.2018.11.001.

[24] M.A. William, A.M. El-Haridi, A.A. Hanafy, A.A. El-Sayed (2019). Assessing The Energy Efficiency Improvement for Hospitals in Egypt Using Building Simulation Modeling. Engineering Research Journal 42 (1): 21-34 https://doi.org/10.21608/erjm.2019.66266.

[25] S. Mahmoud, M. Fahmy, M. Mahdy, I. Elwy, M. Abdelalim (2019). Comparative Energy Performance Simulation for Passive and conventional Design: A Case Study in Cairo, Egypt. Energy Reports6 (1): 699-704. https://doi.org/10.1016/j.egyr.2019.09.052

[26] S.M. Abd El-Rahman, S.I. Esmail, H.B. Khalil, Z. El-Razaz (2020). Sustainable Optimization for Thermal Comfort and Building Energy Efficiency in Cairo. Engineering Research Journal 166: A18-A34. https://doi.org/10.21608/erj.2020.135278

[27] ANSI/ASHRAE/IESNA Standard 90.1-2007.Final Qualitative Determination, ASHRAE (2007).

Title Arabic:
[10] Jttps://doi.org/10.1016/j.proeng.2016.08.029. Buildings in an Oasis-City: Thermal and Energy Assessment of 


\section{تحليل مقارن معتمد علي المحاكاة لتحسين استهلاك الطاقة في المباني الإدارية في مصر المبن}

\section{Arabic Abstract:}

زاد الاهتمام بسمات أغلفة المباني لتحقيق أقل استهلاك طاقة خاصة في الإداي

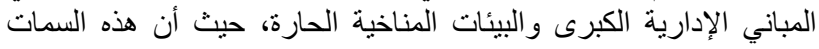

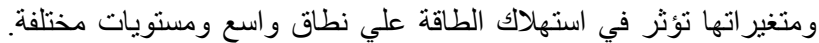

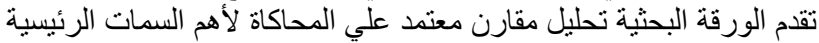

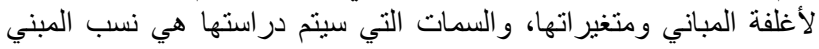

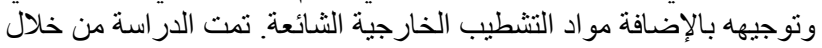

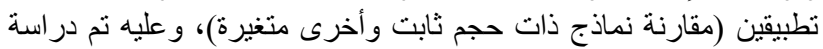

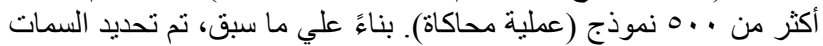

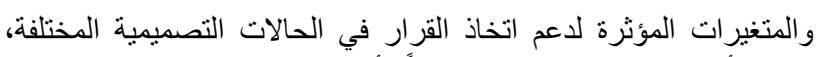

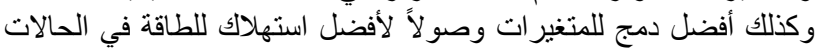

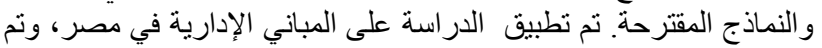

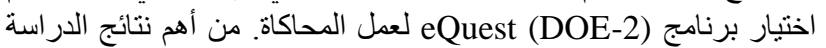

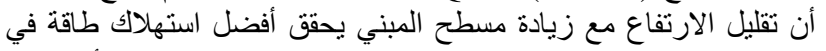

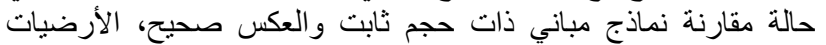

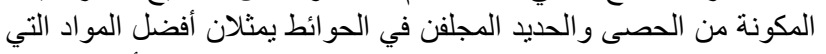

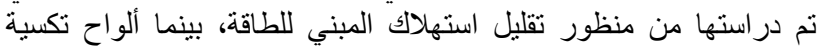

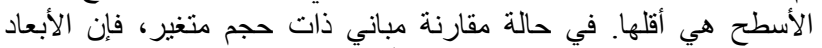

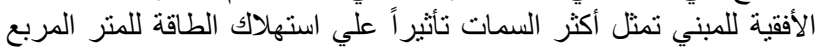

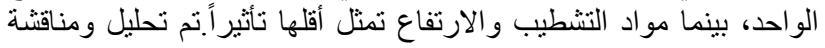

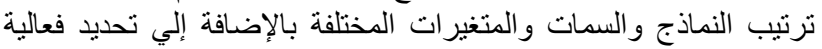

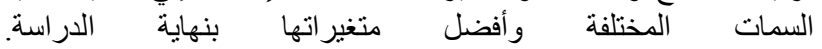

